\title{
A természeti környezetre utaló településnevek kronológiai viszonyai*
}

\author{
KovÁCs ÉvA
}

1. A természeti környezetre utaló településnevek általános problematikája a magyar szakirodalomban ritkán jelenik meg, a kutatók inkább csak azok egy kétségkívül gyakori és jellegzetes típusával, a víznevekből alakult településnevekkel foglalkoztak (vö. pl. BENKŐ 1947, 2003, BÍRÓ 2005, GYŐRFFY 2011: 153-164 stb.). Ezt látva az utóbbi időben én magam kezdtem el tanulmányozni ezt — a mikrotoponimákkal is szoros kapcsolatot mutató - névtípust (KOVÁCs 2017, 2019) annak érdekében, hogy általános jellemzőiről minél pontosabb képet alkothassunk.

Jelen írásomban a természeti környezetre utaló településnevek kronológiai jellemzőit vizsgálom, vagyis arra vagyok kíváncsi, hogy e névtípus egésze és egyes szerkezeti kategóriái mikor és milyen arányban jelentek meg a korai ómagyar kori forrásokban, illetve milyen elmozdulások történtek a gyakoriságukban az évszázadok során. A természeti környezetre utaló településnevekkel kapcsolatos sokféle (pl. kronológiai, strukturális, keletkezéstörténeti, gyakoriságra vonatkozó stb.) kérdés tisztázásához a magyar nyelvterület egészére kiterjedő gazdag történeti névanyagra van szükség: ezt különböző forrásokra támaszkodva (pl. KMHsz. 1., HA. 1-4., Gy. 1-4., Cs. 1-5., KocÁn 2017, Kenyhercz é. n., MÁlyusz 1922/2014, NÉMETH 1997, 2008, BOROVSZKY Pozsony, Somogy, Temes, Torontál, Vas és Zemplén vármegyei kötetei; a forrásokról részletesebben lásd KoVÁCS 2019: 163-164) én magam állítottam össze, és rögzítettem adatbázisban, amely jelenleg 2193 adatból áll. Ez a névállomány szolgál a vizsgálataimhoz alapul.

2. A természeti környezetre utaló településnevek kronológiai jellemzőit a relatív kronológia módszerét alkalmazva igyekszem feltárni. Ehhez elsősorban RÁCZ ANITA legújabb kutatási eredményei (2016a, 2016b) jelentették a mintát számomra. A relatív kronológia mint módszertani eljárás mögött a következő

* A tanulmány az MTA-DE Magyar Nyelv- és Névtörténeti Kutatócsoport programja keretében készült. 
megfontolások húzódnak meg. Egy-egy helynév keletkezési korát az esetek óriási többségében nem tudjuk pontosan megállapítani, hiszen a nevek többnyire nem a keletkezésük pillanatában tünnek fel a forrásokban, hanem akkor, amikor a rögzítésük valamilyen hivatalos ügy (pl. adományozás, per) miatt fontossá válik. Ez azt jelenti, hogy a név keletkezése és lejegyzése között akár igen sok idő is eltelhetett, mivel a név első oklevélbeli rögzítése valójában teljesen független a névadás korától. Emellett a források fennmaradását is véletlenszerü körülmények idézik elö. Ezek miatt a körülmények miatt RÁCZ ANITA úgy véli, hogy bár a nevek első ismert említése esetleges, ez azonban nyilvánvalóan minden egyes nevet egyformán érint, ezért ,az egyes névtípusok relatív (egymáshoz viszonyított) kronológiáját nagyobb névmennyiség esetén az első előfordulások is megbízhatóan kirajzolják" (2016b: 104). Ö maga sikeresen alkalmazta ezt az eljárást a társadalmi csoportnevekből, azaz a nép-, törzs- és foglalkozásnevekből alakult településnevek vizsgálatában (2016a), illetve specifikusan a népnévvel alakult településnevek különböző szerkezeti típusainak (2016b) a relatív kronológiai viszonyait elemezve. TÓTH VALÉRIA a személynévi eredetü helynevek időbeli jellemzőit szintén a relatív kronológia alapján rajzolta meg (2017). A módszer az előzmények tapasztalatai alapján az itt tárgyalt névtípus esetében is eredményes lehet.

3. A relatív kronológiai elemzés különböző típusú településnevek összevetésére alkalmas. Összehasonlítani ugyanakkor csak az azonos feltételek mellett kiválasztott névcsoportokat lehet egymással: mivel én a természeti környezetre utaló helységneveket a Magyar Királyság egész területéről gyüjtöttem össze a korai ómagyar kor időszakából, a viszonyítást is csak ilyen paraméterekkel rendelkező névállományhoz lehet elvégezni.

A természeti környezetre utaló településnevek az ember tevékenységétől függetlenül is létező helyekkel állnak összefüggésben. Érdekes lehet ezért az általam vizsgált névtípussal párhuzamosan azt megnézni, hogy a korai ómagyar korban hogyan alakulnak azoknak a településneveknek a kronológiai jellemzői, amelyek létrejöttében - az itt vizsgált névtípustól eltérően - éppen az ember, az egyén jelenléte játszott szerepet. Ehhez az összevető vizsgálathoz a humán környezetre utaló neveknek egy részkategóriáját, a társadalmi csoportnevekből (a népnévböl, törzsnévböl és foglalkozásnévből) alakult településnevek típusát választottam, ezek relatív kronológiai viszonyait ugyanis jól ismerjük (vö. ehhez RÁCZ 2016a, 2016b, HOFFMANN-RÁCZ-TÓTH 2018: 248-292). E névcsoportok elemzése ugyancsak az ország egész területére kiterjedő, teljesnek tekinthető névállományon alapul. A vizsgált névtípusok ómagyar kori névegyedeinek száma azonban jelentős különbséget mutat, ezt ábrázolja az alábbi diagram (lásd az 1. ábrát; a törzsnévi, a foglalkozásnévi és a népnévi településnevek névegyedeinek együttes számát az 1 . és a 2 . ábrán a könnyebb összevethetőség végett társadalmi csoportnévből alakult névként külön kategóriaként is jelöltem). 


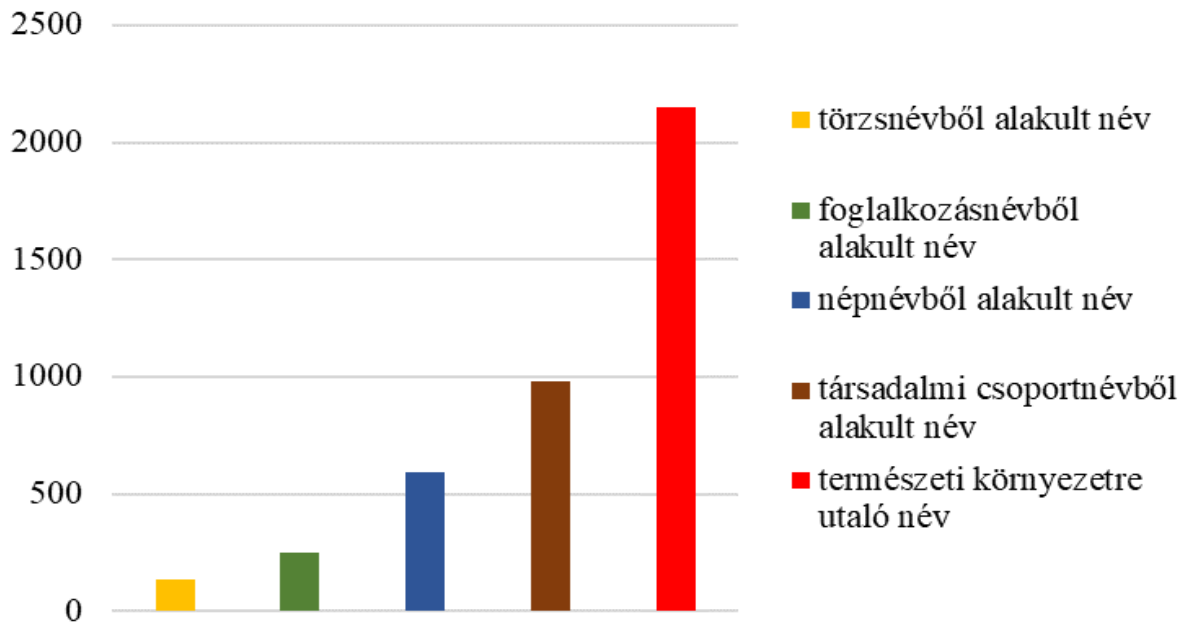

1. ábra. A természeti környezetre utaló és a társadalmi csoportnévből alakult településnevek száma a korai ómagyar korban

Az ábra jól mutatja, hogy a korai ómagyar kori forrásokban legnagyobb számban a természeti környezetre utaló településnevek fordulnak elö, mint például a Patak: 1230: Potahc, t. (Cs. 3: 623, Sopron vm.), Almád: 1249: Almad (Cs. 3: 18, Zala vm.), Agyagtelek: 1288: Agyagthelek (Cs. 3: 218, Veszprém vm.) stb. Az emberi közösségekre utaló társadalmi csoportnevekből alakult településnevek száma messze elmarad az előző típusba tartozó nevekétől. A törzsnévi (pl. Megyer: 1256: Meger, t., Gy. 1: 227, Bács vm.; Kércs: 1262: Kerch, Gy. 1: 110, Abaúj vm.), a foglalkozásnévi (pl. Lovász: 1258>1382: Luaz, Gy. 1: 459, Bars vm.; Csőszi: 1192/1385/1425: Cheuzy, Gy. 1: 217, Bács vm.; Lovásztelek: 1261/1271: Luaztheluk, Gy. 3: 113, Heves vm.) és a népnévi (pl. Német: 1219/1550: Nemeth, Gy. 1: 792, Borsod vm.; Kálozd: 1298: Kaluzd, Gy. 4: 402, Nyitra vm.; Oláhtelek: +1283: Olahteluk, Gy. 1: 647, Bihar vm.) településnevek névegyedeinek együttes száma (lásd 4. oszlop) a természeti viszonyokat tükröző helységnevekének a felét sem teszi ki.

A négy névtípusba tartozó településnevek első említéseinek időbeli megoszlását mutatja a 2. ábra. A névtípusok kronológiai görbéi a következő összefüggésekre világítanak rá. Valamennyi névtípusra jellemző, hogy a 12. század végéig kis számú adattal dokumentálható, ami persze elsősorban az oklevelek kis számával áll összefüggésben. A korai évszázadok természeti környezetre utaló településnévi adatai közül említhetők például a következők: Füzegy: $+1002 /$ [1005 k./+XII.]: Fizeg (Gy. 3: 416, Komárom vm.), Nevegy: +1015/+1158// 1403/PR.: Neuyg, v. (Gy. 4: 660, Pilis vm.), Kékes: [1009]>1261/1271: Kekus (NÉMETH 1997: 105, Szabolcs vm.), Somló: +1015/+1158//1403/PR.: Sumlow, v. 
(KMHsz. 1: 243, Baranya vm.), Ménfö: [1044]: Menfew (Gy. 2: 609, Győr vm.) stb. A társadalmi csoportnevekből alakult településnevek szintén ritkán fordulnak elő a 11-12. században, mint például a törzsnévi eredetü Kürt (1075/+1124/ +1217: Kurth, DHA. 1: 216, Külső-Szolnok vm.), Gyarmat (+1135/1262/1566: Garmoth, Gy. 3: 197, Hont vm.) stb.; a foglalkozásnévböl származó Taszár (1075/+1124/+1217: Tazzar, Gy. 1: 480, Bars vm.), Sarlós (+1058/1300//1403: Sarlos, Gy. 1: 376, Baranya vm.) stb. és a népnévi Besenyö (+1019/+1328/1347: Bessenỹew, DHA. 1: 91, Zala vm.), Csehi $(+[1092] /+1274 / / 1399:$ Chehy, DHA. 1: 283, Somogy vm.) stb. E korai példák ráadásul gyakran bizonytalan kronológiai státuszúak, mivel hamis, másolatban ránk maradt vagy interpolált oklevélből adatolhatók.

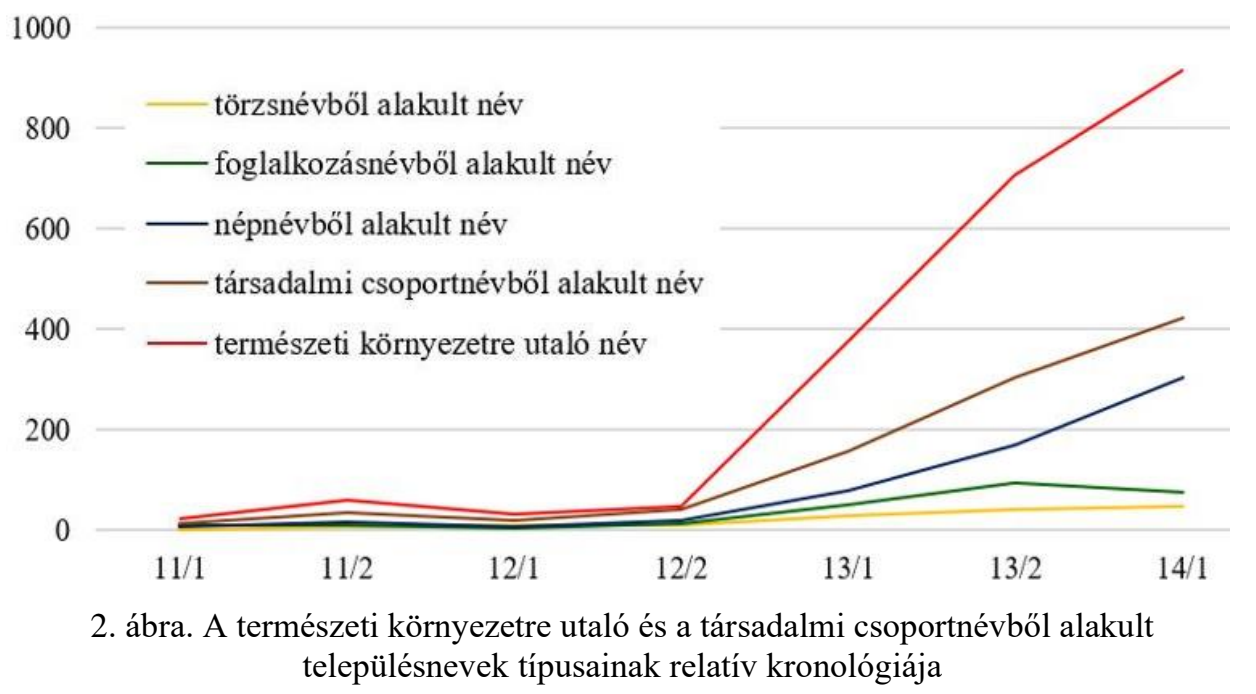

Az e névtípusokba tartozó településnevek számának növekedése - ugyancsak az oklevelek számának gyarapodásával összefüggésben — a 13. század elejétől kezdődően mutatkozik meg, ám a bővülés mennyiségi paramétereit illetően jelentős különbségekre mutathatunk rá.

A törzsnévi és a foglalkozásnévi településnevek időbeli eloszlása szinte teljesen párhuzamosan alakul: e nevek első említéseinek csúcsidőszaka a 13. század második felére tehető, ezután e névtípusok névegyedeinek első feltünése jóval ritkább a forrásokban. A népnévi településnevek első előfordulásainak száma viszont az egész korszakban folyamatosan gyarapszik. A 14. század első felében pedig „öt-hatszor annyi településnév jelentkezik a népnévből keletkezett nevek körében, mint a másik két [ti. törzsnévi és a foglalkozásnévi] névcsoportban" (HOFFMANN-RÁCZ-TÓTH 2018: 248-292). A természeti környezetre utaló településnevek görbéje a társadalmi csoportnévből alakultakéhoz képest a 13. század 
egész időszakában jóval meredekebben ível felfelé (noha a növekedés üteme a 14. század első felében némileg megtörik), és jóval gyakrabban is jelentkeznek ilyen típusú új megnevezések a forrásokban.

Mint láttuk, a korai ómagyar korból adatolható, természeti környezetre utaló településnevek száma bő kétszerese a társadalmi csoportnévből alakultakénak. Ez az arány (2,2-2,3-szeres különbség) mutatkozik meg a 13. század második és a 14. század első felében is. Arról sajnos egyelőre nem tudunk képet alkotni, hogy e névtípusok a korabeli településnév-rendszer egészében milyen szerepet tölthettek be. Viszonyítási alapul szolgálhatnak azonban a Bihar vármegyére vonatkozóan elvégzett vizsgálatok (HOFFMANN-RÁCZ-TÓTH 2018: 377), amely szerint az egyrészes nevek körében az itt elemzett két névcsoport egymáshoz viszonyított aránya a 13. és a 14. század végén ugyancsak $1: 2$ volt (igaz, a szerzők ott a kétrészes neveket külön vizsgálták, ezek figyelembevétele módosítaná némileg az arányokat). Biharban ez az arány a 15 . és a 16 . század végén $1: 2,5$, illetve $1: 3$ értékre módosult a természeti környezetre utaló településnevek javára. $\mathrm{E}$ névtípus az egész névállománynak $\mathrm{kb}$. a $20 \%$-át adta a településnevek számának nagyarányú folyamatos bővülése mellett: azaz Biharban a 13. és a 16. század között a mindenkori névrendszerben minden ötödik településnév természeti környezetre utaló szemantikai tartalmat fejezett ki. A fenti aránybeli megfelelések alapján feltehető, hogy ehhez hasonló arányok jellemezhették az egész korabeli magyar településnév-rendszert is.

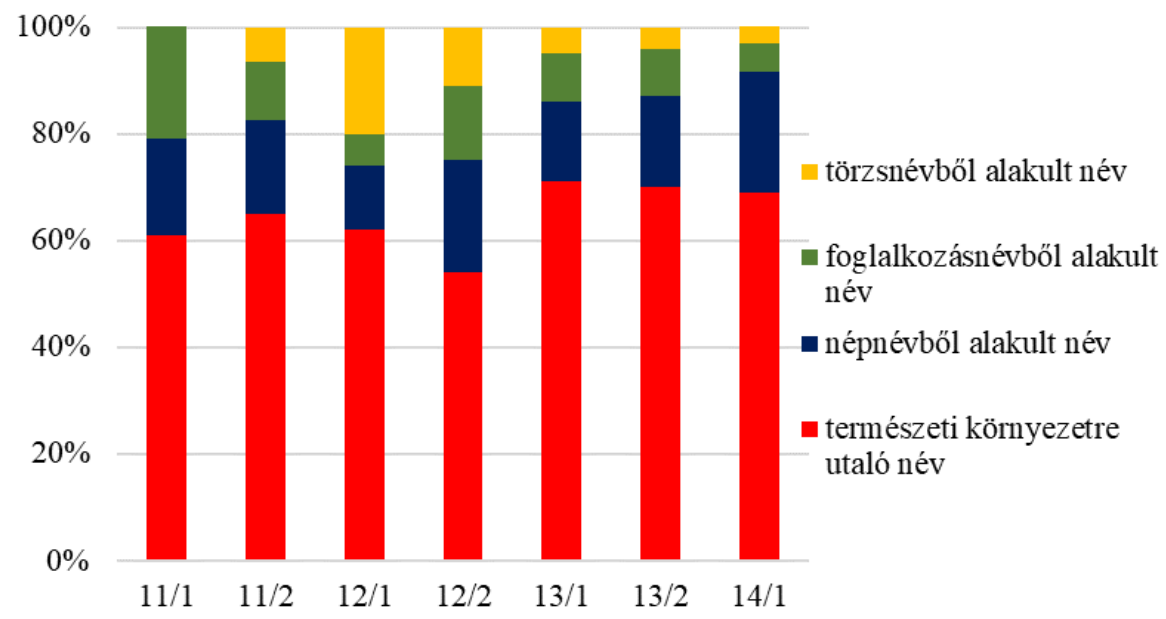

3. ábra. A természeti környezetre utaló és a társadalmi csoportnévből alakult településnevek megoszlása

A 2. ábra természeti környezetre utaló, illetve társadalmi csoportnévből alakult településnévi adatainak mennyiségi összefüggéseit másfajta módon 
megjelenítve (lásd a 3. ábrát) még szemléletesebben kitünik, hogy e névtípusok egymáshoz viszonyított előfordulási aránya alig változott a korai ómagyar kor évszázadaiban: a természeti környezetre utaló településnevek aránya végig $60 \%$ körüli értéket jelez, ettől az értéktől legfeljebb néhány százalékpontnyi értékben tér el. Ez azt jelenti, hogy — más névtípusoktól különbözően — az ide tartozó nevek alakulásmódját, alkotását névadási vagy nyelvi divatok, tendenciák nemigen érintették. Ezt tanúsítják e korra vonatkozóan a fentebb jelzett Bihar vármegyei adatok is.

4. A természeti környezetre utaló településnevek különböző szerkezeti típusokba tartoznak bele. Ezek mennyiségi viszonyait korábbi tanulmányomban mutattam be (KoVÁCs 2019: 164), és megállapítottam, hogy a nevek több mint fele (56\%) formáns nélkül szerepel, egy harmada (34\%) képzőmorfémával van ellátva, és pusztán minden tizedik természeti környezetre utaló településnév tartozik a kétrészes nevek közé. E névszerkezeti típusok relatív kronológiáját elemezve még differenciáltabb képet kaphatunk az első előfordulások időbeli alakulásáról. A 4. ábrával szemléltetett vizsgálat legszembetünőbb tanulsága az, hogy az egyes strukturális típusok gyakoriságának alakulásában bizonyos időszakokban jelentős különbségek mutatkoznak.

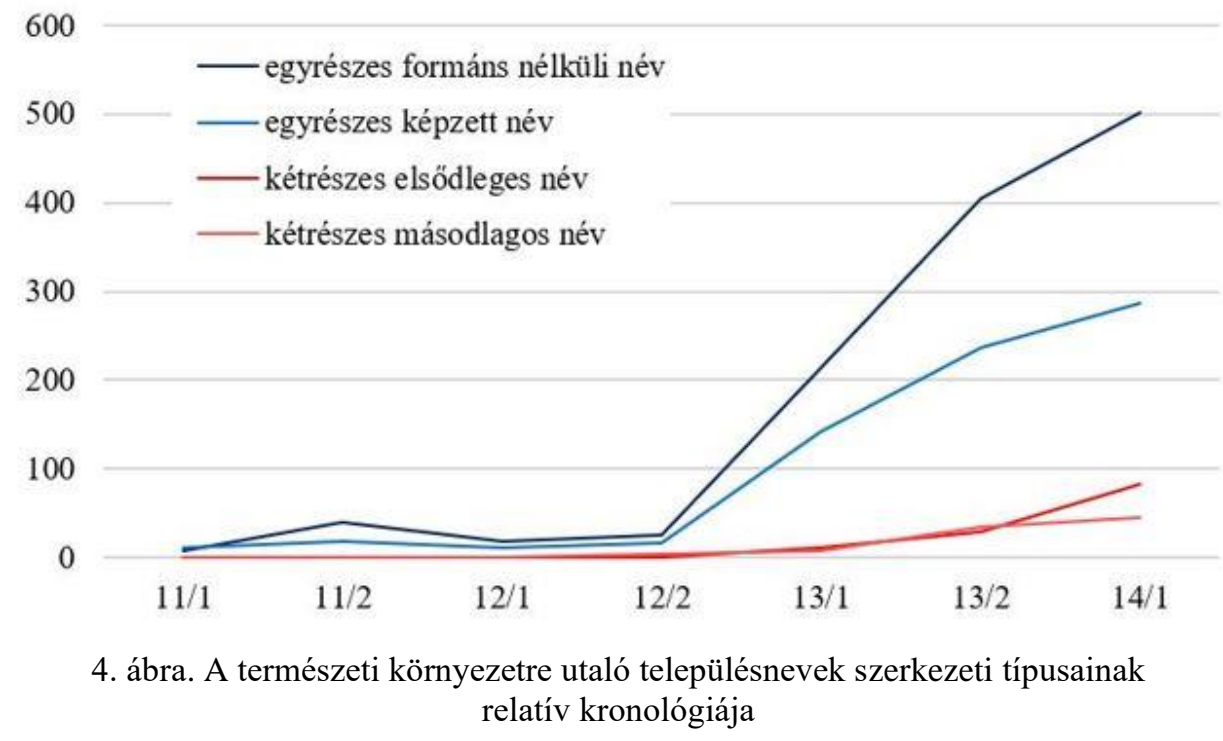

Minthogy a névtípus egészét tekintve a 12. század végéig csupán kevés adattal számolhatunk, e korai időszakokban az egyes szerkezeti típusokban is elenyésző az adatok száma, bár az egyrészes formáns nélküli nevek már itt is fölényben vannak: pl. Kölesér: 1138/1329: Kuleser, v. (KMHsz. 1. 163, Bihar vm.), Föveny: 1192/1374/1425: Fuen (Gy. 2: 385, Fejér vm.), Körtvély: 1208/1359: 
Kurtuel Kurthuel, v. (Gy. 4: 155, Moson vm.), de gyakoribbak a képzett névformák is: pl. Kövesd: 1093: villa Cuesd et alia villa Cuesd iuxta Sopok (Cs. 3: 74, Zala vm.), Erdej: [1077-1095]/+1158//PR: Erdey (Gy. 3: 115, Heves vm.), Egres: 1199: Egris (KMHsz. 1. 88, Csanád vm.). A kétrészes névstruktúrák viszont e korai évszázadokban csak szórványosan, alig egy-két névben — nemegyszer ott is bizonytalan kronológiai státusszal vagy pontosan nehezen megállapítható nyelvi formában — jelentkeznek: pl. Kökeszö: +1135/+1262/1566: Kukezu, pr. (Gy. 3: 207-208, Hont vm.), Kökúthetény: 1198P./PR.: Kequucheton, v. (KMHsz. 1: 163, Bodrog vm.), Somberény: 1193: Sumberhein (Cs. 2: 592, Somogy vm.).

A 13. század elejétől vesznek az egyes struktúrák más-más irányt. A formáns nélküli névszerkezetet mutató településnevek az egész században nagyfokú gyarapodást jeleznek (a természeti környezetre utaló településnevek kronológiai karakterét többségi arányával tulajdonképpen ez a névtípus biztosítja), s a növekedés ütemében a 14. század első felében is csak minimális csökkenés áll be. A képzővel alakult nevek is jelentős arányban vannak jelen a 13-14. században, de a produktivitási-gyakorisági görbéjük az előbbi típusénál laposabb. A metonimikus és a morfematikus névalkotási mód tehát a korai ómagyar kor egész időszakában hozott létre településneveket, a helynévképzővel való névalkotásnak azonban valamivel kisebb szerep jutott a névadásban, mint a korszakban meghatározó formáns nélküli, metonimikus névadásnak.

A kétrészes névstruktúrák időbeli alakulása más ívet rajzol fel: mind az elsődleges, mind a másodlagos településnevek eleve kis számban jelentkeznek a 13-14. században is, de az elsődleges névformákban a 13. század második felében és a 14. században (tehát az egyrészes nevekhez képest később) jól látható növekedés kezdödik, pl. Ágtelek: 1270/1411: Ogteluk Ogthelek, v. (NÉMETH 1997: 19, Szabolcs vm.), Farkasfalva: 1334: Farkasfalua (KocÁn 2017: 95, Ugocsa vm.); Gyöngyöspüspöki: 1261/1271: Gunguspispuky (Gy. 3: 127, Heves vm.), Mezöszentmárton: 1346/1347: Mezewzentmartun (Gy. 4: 520, Pest vm.) stb.

Összességében megállapítható, hogy a magyar helynévrendszerben a természeti viszonyokat tükröző kétrészes településnevek az egyrészes nevekhez képest nemcsak jóval kisebb számban szerepelnek a korai ómagyar kori forrásokban, hanem az egyrészes és a kétrészes elnevezések időbeli viszonyai között is eltérések mutatkoznak.

Ha az itt vázolt folyamatokat az egyik társadalmi csoportnévből, a népnévből alakult településnevekkel összevetve szemléljük, tanulságos eredményekre juthatunk. Az 5. ábra másfajta vizualizációval mutatja be a 4. ábra adatait. Ugyanígy ábrázoltam a 6 . ábrán a népnévből alakult településnevek strukturális típusainak relatív kronológiáját is (ehhez HOFFMANN-RÁCZ-TóTH 2018: 263 diagramjának a korai ómagyar korra vonatkozó része szolgált alapul). 


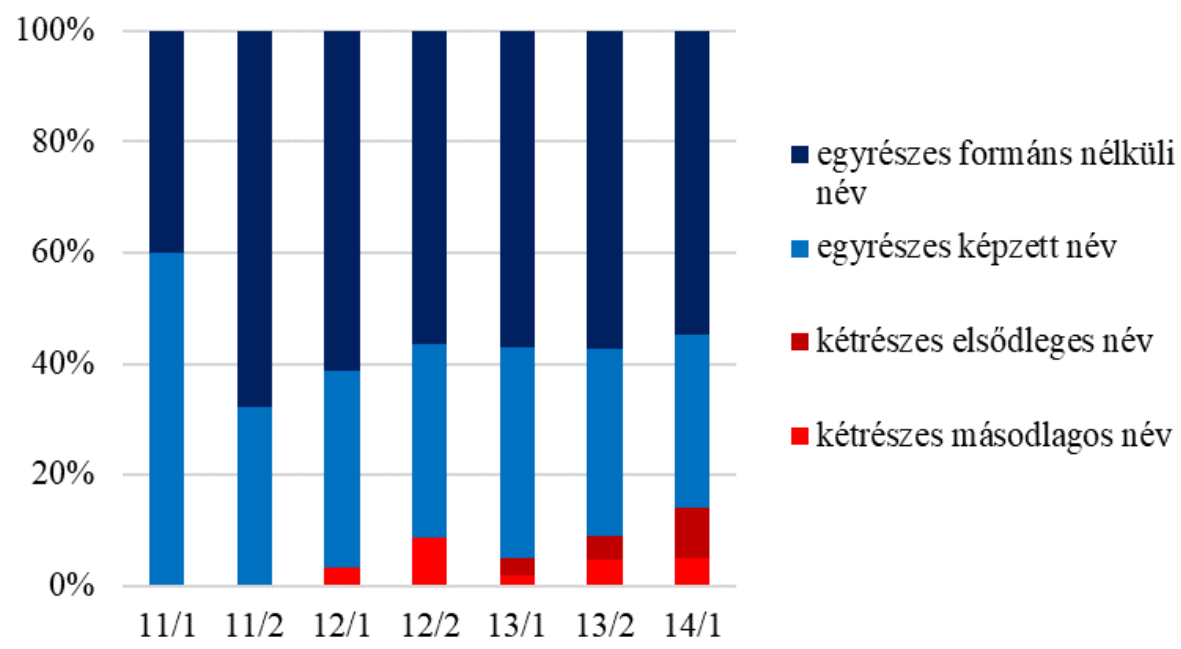

5. ábra. A természeti környezetre utaló településnevek szerkezeti típusainak megoszlása

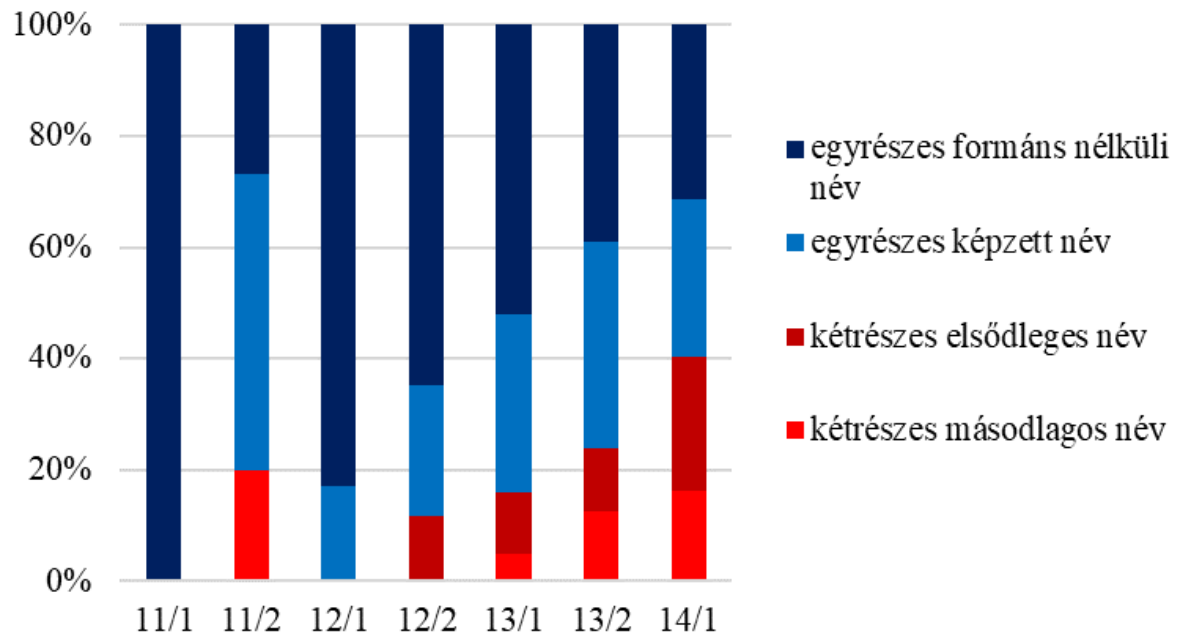

6. ábra. A népnévi eredetü településnevek szerkezeti típusainak megoszlása

A két szemantikai névtípus belső, szerkezeti formák szerint elkülönített csoportjainak időbeli viszonyai között alapvető különbség mutatkozik. A természeti környezetre utaló településnevek körében az egyrészes, formáns nélküli nevek aránya a $12-14$. század között végig $60 \%$ körüli értéket mutat. (A tendenciák értékelésében a 11. századi előfordulások mindkét névtípusban legfeljebb csak érintőlegesen vehetők figyelembe az adatok kis száma miatt.) Kis mértékben 
csökken az egyrészes képzett nevek aránya, mégpedig a kétrészes — föleg elsődleges - nevek némi térnyerése következtében. A népnévi településnevek körében ezek aránya ezzel szemben dinamikusan nő, a 14. század első felében már az e névtípusba tartozó nevek mintegy $40 \%$-át adják. Feltünő az egyrészes formáns nélküli nevek visszaszorulása a 12. század eleji 83\%-ról 31\%-ra. Ez az öszszevetés azt mutatja, hogy - mint ahogyan fentebb a névrendszer egészében a természeti környezetre utaló nevek arányát is viszonylag konstans jellegünek láttuk - az egyes szerkezeti típusainak időbeli viszonyait is ez a kiegyenlítettség jellemzi.

5. Korábban már hivatkozott tanulmányomban bemutattam a természeti környezetre utaló településnevek lexikális-morfológiai típusait is (KOVÁCS 2019: 174-175). Megállapítottam, hogy a természeti környezetre utalás nagyobb részt közszói elemekkel történik (58\%), kisebb részben pedig helynevek fejezik ki ezt a funkciót (42\%). Ezek időbeli viszonyait mutatja a 7. és 8. ábra, amelyekről leolvasható, hogy e két nagy névcsoport egymáshoz viszonyított aránya a korai ómagyar kor időszakában 60\% : 40\% körüli megoszlást jelez. Nem változik lényegesen a természeti környezetre utaló közszavak formáns nélküli és képzővel történő településnévbeli megjelenésének az aránya sem, amely 20\% : 40\% körüli értékeket mutat. Összességében megállapítható tehát, hogy a névcsoport különböző lexikális-morfológiai típusai is nagyfokú időbeli stabilitást mutatnak.

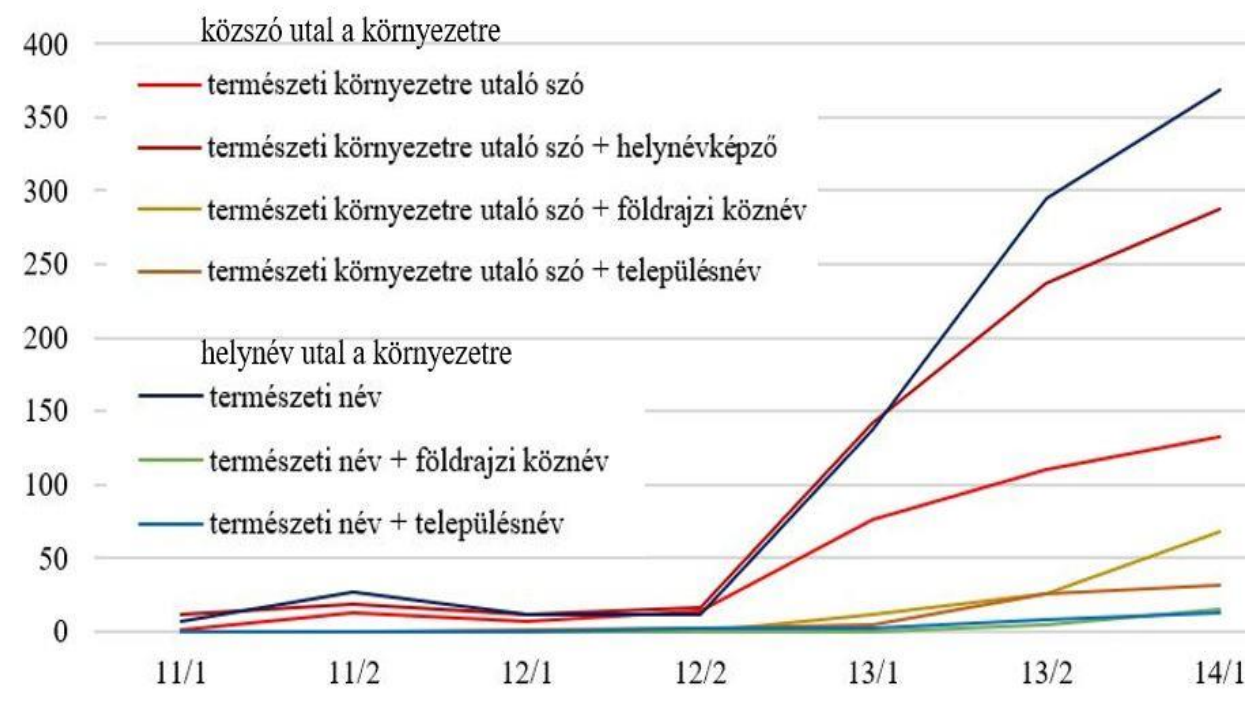

7. ábra. A természeti környezetre utaló településnevek szerkezeti típusainak lexikális-morfológiai alkategóriák szerinti relatív kronológiája 


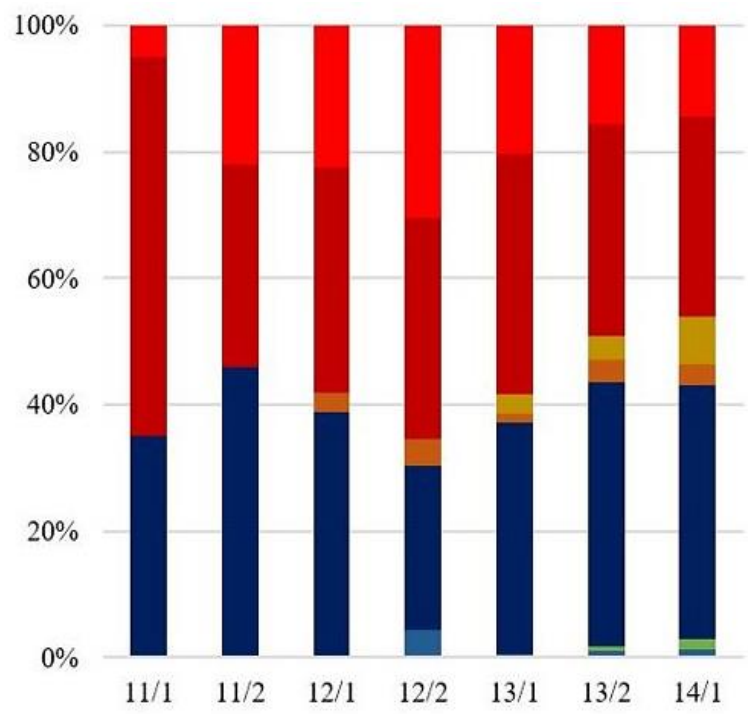

közszó utal a környezetre

घ természeti környezetre utaló szó

घ természeti környezetre utaló szó + helynévképző

- természeti környezetre utaló szó + földrajzi köznév

ت természeti környezetre utaló szó + településnév

helynév utal a környezetre

घ természeti név

घ természeti név + földrajzi köznév

- természeti név + településnév

8. ábra. A természeti környezetre utaló településnevek szerkezeti típusainak lexikálismorfológiai alkategóriák szerinti megoszlása

6. A fentiekből jól látszik, hogy a természeti környezetre utaló településnevek számának jelentős gyarapodása a 13. század elejétől mutatkozik meg, s tart lényegében egyenletes ütemben a korai ómagyar kor végéig. A névrendszer egészében e településnevek aránya — más névtípusoktól, például a társadalmi csoportnévből alakult nevekétől eltérően — viszonylag konstans jellegü. Ez a kiegyenlítettség figyelhető meg a természeti környezetre utaló településnevek egyes szerkezeti típusainak, valamint egyes lexikális-morfológiai típusainak idöbeli viszonyait vizsgálva is. Mindezek a körülmények azt mutatják, hogy szemben más névtípusokkal — az ide tartozó nevek alakulásmódját, alkotását névadási vagy nyelvi divatok, tendenciák nemigen érintették.

\section{Irodalom}

BENKÖ LORÁND 1947. Víz- és helységneveink viszonyához. Magyar Nyelv 43: 259-263.

BENKÖ LORÁND 2003. Beszélnek a múlt nevei. Tanulmányok az Árpád-kori tulajdonnevekről. Budapest, Akadémiai Kiadó.

BÍRÓ FERENC 2005. Víznevekből metonimikusan keletkezett magyar településnevek. Névtani Értesitő 27: 170-179.

BOROVSZKY SAMU 1898. Magyarország vármegyéi és városai. Vas vármegye. Budapest, Magyar Tudományos Akadémia.

BorovszKy SAMu [é. n.]. Magyarország vármegyéi és városai. Pozsony vármegye. Budapest, Magyar Tudományos Akadémia. 
BorovszKy SAMu [é. n.]. Magyarország vármegyéi és városai. Somogy vármegye. Budapest, Magyar Tudományos Akadémia.

BOROVSZKY SAMU [é. n.]. Magyarország vármegyéi és városai. Temes vármegye. Budapest, Magyar Tudományos Akadémia.

BOROVSZKY SAMU [é. n.]. Magyarország vármegyéi és városai. Torontál vármegye. Budapest, Magyar Tudományos Akadémia.

BOROVSZKY SAMU [é. n.]. Magyarország vármegyéi és városai. Zemplén vármegye. Budapest, Magyar Tudományos Akadémia.

Cs. = CSÁNKI DEZSÖ, Magyarország történelmi földrajza a Hunyadiak korában 1-3., 5. Budapest, 1890-1913.

Gy. = GYÖRFFY GYÖRGY, Az Árpád-kori Magyarország történeti földrajza 1-4. Budapest, Akadémiai Kiadó, 1963-1998.

GYŐRFFY ERZSÉBET 2011. Korai ómagyar korifolyóvíznevek. A Magyar Névarchívum Kiadványai 20. Debrecen, Debreceni Egyetemi Kiadó.

HA. = HOFFMANN ISTVÁN-RÁCZ ANITA-TÓTH VALÉRIA szerk., Helynévtörténeti adatok a korai ómagyar korból. 1. Abaúj-Csongrád vármegye. Debrecen, 1997. 2. DobokaGyör vármegye. Debrecen, 1999. 3. Heves-Küküllö vármegye. Debrecen, Debreceni Egyetemi Kiadó, 2012. 4. Liptó-Pilis vármegye. Debrecen, Debreceni Egyetemi Kiadó, 2017.

HoFFMANN ISTVÁN-RÁCZ ANITA-TÓTH VALÉRIA 2018. Régi magyar helynévadás. A korai ómagyar kor helynevei mint a magyar nyelvtörténet forrásai. Budapest, Gondolat Kiadó.

KENYHERCZ RÓBERT é. n. A középkori Szepes vármegye helyneveinek adatbázisa. Kézirat.

KMHsz. = HOFFMANN ISTVÁN szerk., Korai magyar helynévszótár 1000-1350. 1. Abaúj-Csongrád vármegye. A Magyar Névarchívum Kiadványai 10. Debrecen, Debreceni Egyetem Magyar Nyelvtudományi Tanszéke, 2005.

KOCÁN BÉLA 2017. Helynévtörténeti vizsgálatok a régi Ugocsa megyében. A Magyar Névarchívum Kiadványai 45. Debrecen, Debreceni Egyetemi Kiadó.

KovÁCS ÉVA 2017. A természeti környezetre utaló településnevek. Magyar Nyelvjárások 54: $121-135$.

KOVÁCS ÉVA 2019. A természeti környezetre utaló településnevek strukturális kérdései. Helynévtörténeti Tanulmányok 15: 163-178. http://doi.org/10.35528/Helynevtort/15/09

MÁLYUSZ ElEMÉR 1922/2014. Turóc megye kialakulása. [Budapest]. Kiadja a Budavári Tudományos Társaság, 1922. Újraközlése: Historia Incognita 3. sorozat, Máriabesnyö, Attraktor, 2014.

NÉMETH PÉTER 1997. A középkori Szabolcs megye települései. Nyíregyháza, Ethnica Kiadás.

NÉMETH PÉTER 2008. A középkori Szatmár megye települései a XV. század elejéig. Jósa András Múzeum Kiadványai 60. Nyíregyháza.

RÁCZ ANITA 2016a. Régi magyar településnév-típusok relatív kronológiai viszonyai. In: BeNŐ ATTILA-T. SzABÓ Csilla szerk., Az ember és a nyelv-térben és időben. 
Emlékkönyv Szabó T. Attila születésének 110. évfordulóján. Kolozsvár, Erdélyi Múzeum-Egyesület. 50-62.

RÁCZ ANITA 2016b. Etnonimák a régi magyar településnevekben. A Magyar Névarchívum Kiadványai 37. Debrecen, Debreceni Egyetemi Kiadó.

TÓTH VALÉRIA 2017. Személynévi helynévadás az ómagyar korban. A Magyar Névarchívum Kiadványai 41. Debrecen, Debreceni Egyetemi Kiadó.

\section{Chronological Features of Settlement Names Referring to the Natural Environment}

In this paper I examine the chronological features of settlement names referring to the natural environment. My objective is to find out when and in what proportion this name type and its structural categories (names without a formant, single-component and twocomponent names) appeared in sources from the Old Hungarian Era and how their frequency changed during the centuries. My findings based on the relative chronological analysis are compared with the chronological features of the settlement names referring to people. For this comparative study, I chose a subcategory of names referring to the human environment, the type of settlement names formed from the names of social groups (ethnonyms, names of tribes, and occupational names).

Keywords: toponyms from the early Old Hungarian Era, settlement names referring to the natural environment, frequency, relative chronology, comparative studies

Kovács Éva

ORCID: 0000-0002-9111-0728

Debreceni Egyetem kovacs.eva@arts.unideb.hu 